\title{
Evaluation of Carbon Sequestration Potential of Soils-What Is Missing?
}

\author{
Haruna Adamu ${ }^{*}{ }^{\oplus}$, Yuguda Abubakar Umar¹, Hannatu Akanang², Ahmed Sabo1 \\ ${ }^{1}$ Department of Environmental Management Technology, Abubakar Tafawa Balewa University, Bauchi, Nigeria \\ ${ }^{2}$ Department of Chemistry, Abubakar Tafawa Balewa University, Bauchi, Nigeria \\ Email: ^hadamu2@atbu.edu.ng
}

How to cite this paper: Adamu, H., Umar, Y. A., Akanang, H., \& Sabo, A. (2021). Evaluation of Carbon Sequestration Potential of Soils-What Is Missing? Journal of Geoscience and Environment Protection, 9, 39-47. https://doi.org/10.4236/gep.2021.98003

Received: June 25, 2021

Accepted: August 6, 2021

Published: August 9, 2021

Copyright $\odot 2021$ by author(s) and Scientific Research Publishing Inc. This work is licensed under the Creative Commons Attribution International License (CC BY 4.0).

http://creativecommons.org/licenses/by/4.0/ (c) (i) Open Access

\begin{abstract}
It is no doubt that soils are among the Earth's largest terrestrial reservoirs of carbon pool and hold potential for its sequestration and thus, soils can serve as potential way of mitigating the ever-increasing atmospheric $\mathrm{CO}_{2}$ concentration. However, the stability and flux of soil organic carbon are affected in response to changes that are being driven by forms of environmental and anthropogenic factors. Therefore, to establish carbon sequestration potential of soils, an in-depth scientific evaluation that would provide mapping of and speciation of carbon chemical forms, as well as factors influencing the persistence of carbon in soils are key to the process which are beyond quantitative measurements that are conventionally implemented under different land use and/or soil management. This involves soil chemistry, physics, biology, and microbiology. Hence, this short review communication highlights portions of soil chemistry and physics as well as soil biology and microbiology that have not been given attention in determining and/or underpinning decisions on carbon sequestration potential of soils.
\end{abstract}

\section{Keywords}

Soil, Carbon Sequestration Potential, Climate Change, Mitigation

\section{Introduction}

In response to reduce atmospheric $\mathrm{CO}_{2}$ concentration over the next coming years, carbon sequestration potential of soils has been identified as a priority in climate change mitigation strategy (Jackson et al., 2017; Stockmann et al., 2013). The idea was initiated from the soil historical storage capacity of carbon (C), since carbon reservoirs in soil (ca. $2344 \mathrm{Gt}$ in the surface and $3 \mathrm{~m}$ downward) exceed those combined all together both in the atmosphere $(850 \mathrm{Gt})$ and biotic 
pool (560 Gt) (Stockmann et al., 2013). In other words, soils are the main carbon sink as well as source and thus are important components of the global carbon cycle (Faggian et al., 2012), containing about 1206 Pg organic carbon (OC) in the upper $1 \mathrm{~m}$ depth (Hiederer \& Köchy, 2011) which is significantly greater than the atmospheric carbon stock (800 Pg) (Zdruli et al., 2017). This implies that a small increase in the soil carbon stocks can play an important role in reducing greenhouse gases to the atmosphere. For that reason, as part of the contribution to the annual emissions reduction target at the global scale, soil scientists put their interest in carbon sequestration potential of soils. In addition, they further believed that carbon sequestration in soils plays a vital role in combating climate change due to the ability of plants to remove carbon dioxide $\left(\mathrm{CO}_{2}\right)$ from the atmosphere and add to soil, which in turn reducing the warming effect of carbon dioxide down to earth. That has truly promoted the propagation of the value of soils in their role of carbon sequestration. On the other hand, the Kyoto Protocol recognized that net emissions of $\mathrm{CO}_{2}$ can be reduced either by decreasing the rate at which the carbon dioxide is emitted to the atmosphere or by increasing the rate at which $\mathrm{CO}_{2}$ is removed from the atmosphere through sinks (Lal, 2001). In the quest to achieve that, soils are among the Earth's largest reservoirs of carbon and thus, their carbon sequestration potential is indisputable. Consequently, soils can provide a future way of mitigating the ever increasing atmospheric level of $\mathrm{CO}_{2}$. Hence, for nearly two (2) decades, soil scientists have studied and estimated the potential of sequestering carbon in soil quantitatively by cross-sectional method (Lal, 2001, 1999), which has been the most widely applied technique. Under the cross-sectional method, carbon sequestration potential of soils in a particular area is determined using two different land-use types disturbed (Decreting) and undisturbed (Accreting), where the calculated difference of carbon stock concerning the two different land-use serves as a measure of carbon sequestration potential of the soils of the area under investigation. Unfortunately, such technical expression of carbon sequestration potential of soils is fundamentally and scientifically inadequate. The methodology is just hype and an inexplicit tool for quantifying and predicting carbon sequestration potential of soils. Because there are a lot of questions needed to be asked! However, it is only with an in-depth knowledge that cut across between biological and physical sciences can actually foretell about carbon sequestration potential and suitability of soils before that terrestrial component of the Earth can be regarded as "considerable" sink for atmospheric carbon dioxide $\left(\mathrm{CO}_{2}\right)$.

Even though soils can act as both sources and sinks of carbon, biomass input levels, micro-climatic conditions, biochem-climatic changes, as well as environmental driving forces and conditions are imperatively important factors needed for the scientific prediction of carbon sequestration potential of soils (Lehmann \& Kleber, 2015; Thomson et al., 2015; Smith et al., 2012). It also involves the necessary understanding of the underlying mechanisms of carbon stabilization and the imaginable processes of its destabilization in soil environment. This is because carbon is rarely stored in soils in its elemental form, but rather in its or- 
ganic form that contains significant amounts of other nutrients more than all the nitrogen-based nutrients in soils (Van Groenigen, 2017). For this reason, biomass productivity, the type of vegetation, water and nutrients availability and mobility, among other constraints can therefore be major limiting factors deterring carbon sequestration potential of soils (Lal, 2002). In addition, other co-multiple factors including water infiltration viability, water holding capacity and ecological resilience/elasticity also play a vital role in increasing the carbon sequestration potential of soils (Zomer et al., 2017). Therefore, in an attempt to know the potential of soils to sequester carbon in places where can be abundantly stocked, soil chemistry and physics as well as soil biology and microbiology need to be accommodated too in the conventional methods (e.g., cross-sectional method) and this can better provide high decision independence on predicting carbon sequestration potential of soils. Accordingly, this short communication highlights portions of soil chemistry and physics as well as soil biology and microbiology that have not been given attention in determining and/or underpinning decisions on carbon sequestration potential of soils.

\section{Carbon Sequestration Potential of Soils-What Are the Missing Sciences?}

\subsection{Chemical and Physical Processes Affecting Soil Organic Carbon Stabilization-The Soil Chemistry}

Despite the fact that soils function as carbon reservoirs, it has also been projected that in certain circumstances, soils may also be reasonably strong sources of $\mathrm{CO}_{2}$ in the future as temperature rises continuously (Sitch et al., 2008). For example, it has been argued that the amount of $\mathrm{CO}_{2}$ released into the atmosphere as a result of soil microbial activities is much higher than the amount released due to human activities. According to (Crowther et al., 2015), the amount of atmospheric $\mathrm{CO}_{2}$ produced due to microbial decomposition on annual basis is 7.5 - 9 times more than that released due to anthropogenic emissions worldwide. A similar earlier report indicated that through the decomposition of plant organic matter, microbial communities in the soil could release $5.5 \times 10^{12} \mathrm{Kg}(5.5$ billion tons) of $\mathrm{CO}_{2}$ annually, which is eight times more than that released due to human activities (Zimmer, 2010). This scenario has a tremendous influence on the carbon cycle-climate feedback, which is the basis upon which the Intergovernmental panel makes projections on climate change (Crowther et al., 2015). Consequently, regardless of the soil importance in stocking pools of carbon, indeed there need to consider stabilization mechanisms of organic carbon in soil environment while attempting to determine the potential of soils for carbon sequestration. It has been scientifically proven that the stability of soil organic carbon is controlled by the three main physico-chemical stabilization processes, namely: 1) Protection and preservation of complex organic compounds within the soil aggregates, which translates to spatial inaccessibility of soil microbes to organic compounds and a limitation on $\mathrm{O}_{2}$ availability (Schmidt et al., 2011); 2) Soil organic carbon interactions with mineral surfaces and metal 
ions, as there is a strong correlation between the soil clay mineral phase and the various forms of soil organic carbon due to organo-mineral associations (Kleber et al., 2007); 3) Physical inaccessibility of occluded soil organic carbon to ecological stresses and microbial communities and extracellular enzymes (Dungait et al., 2012; Solomon et al., 2012). These aspects of physical and physical organic chemistry are of importance because each or all provide(s) a priori limits to the soil carbon sequestration potential (Stockmann et al., 2013), which can be affected through the surface properties of minerals such as functional groups and charge of the soil organic moiety and capacity for soil aggregation and stability (controlled by soil particle size distribution).

Therefore, with the recognition of the importance of soil organic carbon speciation and fractionation in probing carbon sequestration potential of soils, it becomes important to stress that aspects of carbon speciation and fractionation in soil environments are the fundamentals to help better understanding the specific carbon specie(s) that are thermodynamically stable and inert or unstable and also kinetically labile based on which of the fraction(s) of soil carbon is/are either in exchangeable, soluble, oxidizable, reducible and residual (organics bound and occluded to soil silicates). In fact, these are what would really explain about persistence and permenance of carbon in soil environment and in turn establish the carbon sequestration potential of soils in a specific time and at a particular location.

\subsection{Biological and Microbiological Processes Affecting Soil Organic Carbon Stabilization-The Soil Biology and Microbiology}

Recently, stable isotopic study has shown that the residence time of soil organic compounds is independent to its chemical composition (Hernandez-Soriano et al., 2018; Stockmann et al., 2013). This has explained that relative chemical complexity of soil organic constituents only helps define short-term bio-decomposition at seasonal scales and it does not explain soil organic matter bio-decomposition in the long term (e.g., decades and/or centuries). For example, the different carbon pools existing in the soil environments have different average residence times, ranging from one year to a few years to decades or more than 1000 years (stable fraction), which largely depend on the biochemical composition of the soil carbon source (e.g., lignin is more stable than cellulose) (Robert, 2001). However, the mineralization of soil organic constituents is often directly connected to chemical complexity (e.g., their molecular size and reactivity) through soil microbial communities correlated to specific activity and/or composition of the soil organic carbons (Fontaine \& Bardot, 2005; Marschner \& Kalbitz, 2003). This translates to some connection between chemical composition and bio-mineralization associated with the kind of protection or the type of bonds. For instance, stable carbon fractions are protected or sequestered either physically and/or chemically, of which by definition "physical" means an encapsulation of organic carbon fragments by clay particles or soil macro- or micro-aggregates and "chemical" 
refers to specific bonds of organic carbon with colloid or clay constituents of soil (Balesdent et al., 2000) and as a result, can withstand microbial mineralization. This means that physical and chemical protection and/or sequestration controls bioavailability and biodegradability of organic carbons in soils. It is, therefore, appropriate to say that where bio-mineralization is more severe, the soil organic carbon is generally expected to be biochemically broken into $\mathrm{CO}_{2}$.

In the same context of use stable isotope of $\delta^{13} \mathrm{C}$, isotopic analysis can also partition the dynamics of soil carbon in relation to release of $\mathrm{CO}_{2}$ from soils to the atmospheric environment by respiratory process through plant-microbe soil spectrum (Hernandez-Soriano et al., 2018; Högberg et al., 2008). In addition, it has been established that the release of $\mathrm{CO}_{2}$ from soil to the atmosphere occurs through combined activities, namely: 1) Root respiration (autotrophic) and 2) $\mathrm{Mi}$ cro- and macro-organisms decomposing (heterotrophic respiration) debris and organic matter in soil (Högberg et al., 2005). As each of these components returns soil carbon to the atmosphere on different average time scales, the partitioning of heterotrophic and autotrophic sources of release of $\mathrm{CO}_{2}$ to atmospheric environment using isotopic analysis is therefore a very promising tool that can reveal the dynamic and static state of soil carbon and the capacity of soil to sequester it depending on the dominance of one source of release of $\mathrm{CO}_{2}$ than the other.

In addition, rich plant diversity can increase soil organic carbon, because much of the influence of individual plant species on soil microbial activity on carbon and nutrient cycling is through the quality and quantity of organic carbon returning to the soil (Stockmann et al., 2013). In support of this, plant species that host $\mathrm{N}$-fixing bacteria (such as legumes) or root systems with mycorrhizal associations, most often enhance nutrient uptake and can provide a biochemical reaction pathway for the return of carbon substrate directly to microbes and soil simultaneously (Kogel-Knabner \& Rumpel, 2018). Therefore, in a situation like that, the increase of carbon stocks in soils is most likely influenced by decomposition processes. In a similar attempt, study showed that Eucalyptus species that are potently $\mathrm{N}$-fixing trees increased soil nitrogen $(\mathrm{N})$ availability and likewise the potential to sequester soil organic carbon (Resh et al., 2002; Kaye et al., 2000). This suggests that some plant species tend to add more fresh carbon to the soils while others are more preferentially to decompose all older forms of carbon. Overall, biological and micro-biological processes also contribute to addition and depletion of soil organic carbon stocks depending on the responsive evidence(s), which either supporting or opposing potential of soils to sequester carbon.

\subsection{Function of Cohesive and Adhesive Forces (Internal and External Frictions) in Dynamics and Kinematics of Flow of Fluids Relative to Infiltration of Soil Solutes-The Soil Physics}

On the stability and fluidity of soil organic carbon, soil fluids and temperature also exert strong control on decomposition and mineralization processes of soil organic carbon. It is certain that temperature sensitivity varies among different 
fractions of soil carbon pools (e.g., labile vs stable) and such are tight to cohesive and adhesive forces that exist within organic carbon composition as well as between organic carbon and the soil environment. A change of soil compaction from close-fitted to loose-fitted at depth stimulates mineralization of olden soil carbon buried underneath due to ease of distribution of fresh carbon at depth and potential release of carbon buried at depth by deep-rooted plants. In addition, increased soil aeration and intense disruption of cohesive forces that bind soil aggregates are the main factors stimulating mineralization of soil organic carbon by the soil micro-organisms. Similarly, carbon sequestration potential of soils may also be influenced by localized and controlled processes in soil ecosystem which including rainfall and soil fluids infiltration, soil erosion and deposition of solutes govern by soil gradient heterogeneity-All of which can affect carbon input and carbon loss rates (Ontl \& Schulte, 2012). Therefore, soil particles binding forces control aggregation, texture and dynamics of organic carbon pools in macro- and micro-aggregates of soils. Consequently, bulkiness of soil aggregates has a great effect on the hydraulic of soil carbon solutes.

Despite somehow controversial, conventional viewers hold that the mineralization rate of soil organic carbon is independent of the size, structure or texture of soils (Stockmann et al., 2013). However, it has been argued that the rate limiting step in soil organic carbon mineralization is governed by abiotic rather than biotic (particularly microbial) processes, which is termed as the "Regulatory Gate" for soil organic carbon mineralization process (Kemmitt et al., 2008). The "Regulatory Gate" hypothesis processes including among others, specifically, diffusion and adsorption/desorption from soil surfaces, which control over carbon stocks in the soil. This indicates that carbon sequestration potential of soils is finite because soils' carbon sequestration saturation limits are controlled by inherent soil cohesion and adhesion to mineral particles. From this, soil physics also provides better understanding of the significance of abiotic mechanisms of protection of carbon in soil environment, which in turn can guide decision on the capacity or potential of soils to sequester carbon.

\section{Conclusion}

The discussion concluded that though soils are likely to help us remediate the confronting climate change induced by influx emission of $\mathrm{CO}_{2}$ alongside with the other greenhouse gases, carbon sequestration potential of soils projected by conventional approaches such as cross-sectional requires additional scientific considerations for the irrefutable deduction. Such scientific considerations are best situated within a framework of in-depth scrutiny involving soil chemistry, physics, biology, and microbiology. This implies that overall in-situ soil architecture is required to underpin decisions on the potential of soils for carbon sequestration. Therefore, the cross-sectional method which mainly involves quantitative measurements of carbon stock in soils requires inclusion of scientific mapping of and speciation of carbon chemical forms as well as environmental 
factors (both induced by natural and anthropogenic causes) influencing the persistence of carbon in soils.

In addition, the most important conclusions from this short review are:

1) The determination of total concentrations of the soil organic carbon in a sample is inadequate to support carbon sequestration potential of soil since this information alone will not reflect, for example, the biophysically transformed forms of organic carbon with different behaviour in the soil environment.

2) In the literature, sufficient reports are lacking that establish including the relation between biophysical limiting factors in the soil environment and carbon sequestration potential of soil itself.

3) The most important knowledge gap identified includes: a) The effect of uncontrolled removal of soil organic carbon stored at the surface of soil environment causes by infiltration of precipitation that altering moisture regime and the vertical redistribution of soil organic carbon budget in the soil profile has been neglected; b) The relation between carbon sequestration potential of soil and mobility mechanism of soil organic carbon, soil organic carbon volatility and mobility mechanics, and dynamics of organic carbon packing and freeing is to large extent unknown. Thus, in order to make irrefutable inferences to support the decision on carbon sequestration potential of soil, many biophysical research inputs are required which are including the key areas identified above.

\section{Conflicts of Interest}

The authors declare no conflicts of interest regarding the publication of this paper.

\section{References}

Balesdent, J., Chenu, C., \& Balabane, M. (2000). Relationship of Soil Organic Matter Dynamics to Physical Protection and Tillage. Soil \& Tillage Research, 53, 215-220. https://doi.org/10.1016/S0167-1987(99)00107-5

Crowther, T. W., Thomas, S. M., Maynard, D. S., Baldrian, P., Covey, K., Frey, S. D, van Diepen, L. T. A., \& Bradford, M. A. (2015). Biotic Interactions Mediate Soil Microbial Feedbacks to Climate Change. Proceedings of the National Academy of Sciences of the United States of America, 112, 7033-7038. https://doi.org/10.1073/pnas.1502956112

Dungait, J. A. J., Hopkins, D. W., Gregory, A. S., \& Whitmore, A. P. (2012). Soil Organic Matter Turnover is Governed by Accessibility not Recalcitrance. Global Change Biology, 18, 1781-1796. https://doi.org/10.1111/j.1365-2486.2012.02665.x

Faggian, V., Bini, C., \& Zilioli, D. M. (2012). Carbon Stock Evaluation from Topsoil of Forest Stands in NE Italy. International Journal of Phytoremediation, 14, 415-428. https://doi.org/10.1080/15226514.2011.620656

Fontaine, S., \& Bardot, S. (2005). Size and Functional Diversity of Microbe Populations Control, Plant Persistence and Long-term Soil Carbon Accumulation. Ecology Letters, 8, 1075-1087. https://doi.org/10.1111/j.1461-0248.2005.00813.x

Hernandez-Soriano, M. C., Dalal, R. C., Warren, F. J., Wang, P., Green, K., Tobin, M. J., Menzies, N. W., \& Kopittke, P. M. (2018). Soil Organic Carbon Stabilization: Mapping Carbon Speciation from Intact Microaggregates. Environmental Science \& Technology, 
52, 12275-12284. https://doi.org/10.1021/acs.est.8b03095

Hiederer, R., \& Köchy, M. (2011). Global Soil Organic Carbon Estimates and the Harmonized World Soil Database. Publication Office of the European Union.

Högberg, P., Högberg, M. N., Gottlicher, S. G., Betson, N. R., Keel, S. G., Metcalfe, D. B., Campbell, C., Schindlbacher, A., Hurry, V., Lundmark, T., Linder, S., \& Nasholm, T. (2008). High Temporal Resolution Tracing of Photosynthate Carbon from the Tree Canopy to Forest Soil Microorganisms. New Phytologist, 177, 220-228. https://doi.org/10.1111/j.1469-8137.2007.02238.x

Högberg, P., Nordgren, A., Högberg, M. N., Ottosson-Löfvenius, M., BhupinderpalSingh, Olsson, P., \& Linder, S. (2005). Fractional Contributions by Autotrophic and Heterotrophic Respiration to Soil-Surface $\mathrm{CO}_{2}$ Efflux in Boreal Forests. In H. Griffiths, \& P. G. Jarvis (Eds.), The Carbon Balance of Forest Biomes (pp. 251-267). Taylor \& Francis. https://doi.org/10.4324/9780203501344-12

Jackson, R. B., Le Quéré, C., Andrew, R. M., Canadell, J. G., Peters, G. P., Roy, J., \& Wu, L. (2017). Warning Signs for Stabilizing Global $\mathrm{CO}_{2}$ Emissions. Environmental Research Letters, 12, Article ID: 110202. https://doi.org/10.1088/1748-9326/aa9662

Kaye, J. P., Resh, S., Kaye, M. W., \& Chimner, R. A. (2000). Nutrient and Carbon Dynamics in a Replacement Series of Eucalyptus and Alzbibia Trees. Ecology, 81, 3267-3273. https://doi.org/10.2307/177491

Kemmitt, S. J., Lanyon, C. V., Waite, I. S., Wen, Q., Addiscott, T. M., Bird, N. R. A., O’Donnell, T., \& Brookes, P. C. (2008). Mineralisation of Native Soil Organic Matter Is not Regulated by the Size, Activity or Composition of the Soil Microbial Biomass-A New Perspective. Soil Biology and Biochemistry, 40, 61-73.

https://doi.org/10.1016/j.soilbio.2007.06.021

Kleber, M., Sollins, P., \& Sutton, R. A. (2007). Conceptual Model of Organo-mineral Interactions in Soils: Self-Assembly of Organic Molecular Fragments into Zonal Structures on Mineral Surfaces. Biogeochemistry, 85, 9-24.

https://doi.org/10.1007/s10533-007-9103-5

Kogel-Knabner, I., \& Rumpel, C. (2018). Advances in Molecular Approaches for Understanding Soil Organic Matter Composition, Origin, and Turnover: A Historical Overview. Advances in Agronomy, 149, 1-48. https://doi.org/10.1016/bs.agron.2018.01.003

Lal, R. (1999). Soil Management and Restoration for C Sequestration to Mitigate the Accelerated Greenhouse Effect. Progress in Environmental Science, 1, 307-326.

Lal, R. (2001). Potential of Desertification Control to Sequester Carbon and Mitigate the Greenhouse Effect. Climatic Change, 15, 35-72. https://doi.org/10.1023/A:1017529816140

Lal, R. (2002). Soil Carbon Dynamics in Cropland and Rangeland. Environmental Pollution, 116, 353-362. https://doi.org/10.1016/S0269-7491(01)00211-1

Lehmann, J., \& Kleber, M. (2015). The Contentious Nature of Soil Organic Matter. Nature, 528, 60-68. https://doi.org/10.1038/nature16069

Marschner, B., \& Kalbitz, K. (2003). Controls of Bioavailability and Biodegradability of Dissolved Organic Matter in Soils. Geoderma, 133, 211-235. https://doi.org/10.1016/S0016-7061(02)00362-2

Ontl, T. A., \& Schulte, L. A. (2012). Soil Carbon Storage. Nature Education Knowledge, 3, 35.

Resh, S. C., Binkley, D., \& Parrotta, J. A. (2002). Greater Soil Carbon Sequestration under Nitrogen-Fixing Trees Compared with Eucalyptus species. Ecosystems, 5, 217-231. https://doi.org/10.1007/s10021-001-0067-3

Robert, M. (2001). Soil Carbon Sequestration for Improved Land Management. FAO.

Schmidt, M. W. I., Torn, M. S., Abiven, S. Dittmar, T., Guggenberger, G., Janssens, I. A., 
Kleber, M., Kogel-Knabner, I., Lehmann, J., Manning, D. A. C., Nannipieri, P., Rasse, D. P., Weiner, S., \& Trumbore, S. E. (2011). Persistence of Soil Organic Matter as an Ecosystem Property. Nature, 478, 49-56. https://doi.org/10.1038/nature10386

Sitch, S., Huntingford, C., Gedney, N., Levy, P. E., Lomas, M., Piao, S. L., Betts, R., Ciais, P., Cox, P., Friedlingstein, P., Jones, C. D., Prentice, I. C., \& Woodward, F. I. (2008). Evaluation of the Terrestrial Carbon Cycle, Future Plant Geography and ClimateCarbon Cycle Feedbacks Using Five Dynamic Global Vegetation Models (DGVMs). Global Change Biology, 14, 2015-2039. https://doi.org/10.1111/j.1365-2486.2008.01626.x

Smith, P., Davies, C. A., Ogle, S., Zanchi, G., Bellarby, J., Bird, N., Boddey, R.M., McNamara, N. P., Powlson, D., Cowie, A., van Noordwijk, M., Davis, S. C., Richter, D. D. E. B., Kryzanowski, L., van Wijk, M. T., Stuart, J., Kirton, A., Eggar, D., Newton-Cross, G., Adhya, T. K., \& Braimoh, A. K. (2012). Towards an Integrated Global Framework to Assess the Impacts of Land use and Management Change on Soil Carbon: Current Capability and Future Vision. Global Change Biology, 18, 2089-2101.

https://doi.org/10.1111/j.1365-2486.2012.02689.x

Solomon, D., Lehmann, J., Harden, J., Wang, J., Kinyangi, J., Heymann, K., Karunakaran, C., Lu, Y., Wirick, S., \& Jacobsen, C. (2012). Microand Nano-Environments of Carbon Sequestration: Multi-Element STXM-NEXAFS Spectromicroscopy Assessment of Microbial Carbon and Mineral Associations. Chemical Geology, 329, 53-73.

https://doi.org/10.1016/j.chemgeo.2012.02.002

Stockmann, U., Adams, M. A., Crawford, J. W., Field, D. J., Henakaarchchi, N., Jenkins, M., Minasny, B., McBratney, A. B., Courcelles, V. D. R. D., Singh, K., Wheeler, I., Abbott, L., Angers, D. A., Baldock, J., Bird, M., Brookes, P. C., Chenu, C., Jastrow, J. D., Lal, R., Lehmann, J., O’Donnell, A. G., Parton, W. J., Whitehead, D., \& Zimmermann, M. (2013). The Knowns, Known Unknowns and Unknowns of Sequestration of Soil Organic Carbon. Agriculture, Ecosystems \& Environment, 164, 80-99. https://doi.org/10.1016/j.agee.2012.10.001

Thomson, B. C., Tisserant, E., Plassart, P., Uroz, S., Griffiths, R. I., Hannula, S. E., Buée, M., Mougel, C., Ranjard, L., Van Veen, J. A., Martin, F., Bailey, M. J., \& Lemanceau, P. (2015). Soil Conditions and Land-Use Intensification Effects on Soil Microbial Communities across a Range of European Field Sites. Soil Biology and Biochemistry, 88, 403-413. https://doi.org/10.1016/j.soilbio.2015.06.012

Van Groenigen, J. W, Van Kessel, C., Hungate B. A., Oenema, O., Van Powlson, D. S., \& Groenigen, K. J. (2017). Sequestering Soil Organic Carbon: A Nitrogen Dilemma. Environ. SciTechnol, 51, 4738-4739. https://doi.org/10.1021/acs.est.7b01427

Zdruli, P., Lal, R., Cherlet, M., \& Kapur, S. (2017). New World Atlas of Desertification and Issues of Carbon Sequestration, Organic Carbon Stocks, Nutrient Depletion and Implications for Food Security. In S. Erşahin, S. Kapur, E. Akça, A. Namlı, \& H. E. Erdoğan (Eds.), Carbon Management, Technologies, and Trends in Mediterranean Ecosystems (pp. 13-25). Springer. https://doi.org/10.1007/978-3-319-45035-3_2

Zimmer, C. (2010). The Microbe Factor and its Role in our Climate Future. Yale School of the Environment.

http://e360.yale.edu/feature/the_microbe_factor_and_its_role_in_our_climate_future/ $\underline{2279 /}$

Zomer, R. J., Bossio, D. A., Sommer, R., \& Verchot, L. V. (2017). Global Sequestration Potential of Increased Organic Carbon in Cropland Soils. Scientific Reports, 7, 1-8.

https://doi.org/10.1038/s41598-017-15794-8 